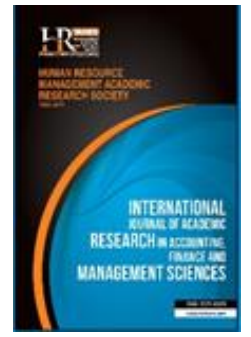

International Journal of Academic Research in Accounting, Finance and Management Sciences

Vol. 9, No.1, January 2019, pp. 42-53

E-ISSN: 2225-8329, P-ISSN: 2308-0337

(c) 2018 HRMARS

www.hrmars.com

To cite this article: Wanjau, N. C., Kiragu, D., Riro, K. (2019). Members' Characteristics and Financial Performance among Primary Marketing Co-Operatives in Nyeri County Kenya, International Journal of Academic Research in Accounting, Finance and Management Sciences 9 (1): $42-53$

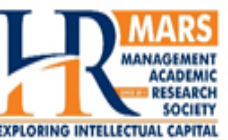

http://dx.doi.org/10.6007/IJARAFMS/v9-i1/5723 (DOI: 10.6007/IJARAFMS/v9-i1/5723)

\title{
Members' Characteristics and Financial Performance among Primary Marketing Co-Operatives in Nyeri County Kenya
}

\author{
Ndung'u Charles Wanjau' ${ }^{1}$, David Kiragu², Kamau Riro \\ ${ }^{1}$ Master of Business Administration Student \\ ${ }^{2,3}$ School of Business Management and Economics, Dedan Kimathi University of Technology, Kenya
}

Abstract

Financial performance deals with measuring the results of a firm's operations which is reflected in its profitability as well as return on investment. Financial performance of Primary Marketing Co-operatives is influenced by many factors both within and outside the respective Co-operatives scope. Kenyan Marketing Co-operatives provide opportunities for employment, resource mobilization and suitable structured development all aimed at reduction of poverty levels and impacting positively on the lives of people. The above goals are greatly hampered by the myriad of challenges faced by Primary Marketing Co-operatives resulting to slow growth, underperformance and ineffective service delivery. This study therefore sought to examine how members' characteristics influence financial performance of Primary Marketing Co-operatives in Nyeri County. The study employed four theories that included Agency Theory, Stewardship Theory, Stakeholder Theory and Resource Based Theory. The study took a descriptive research design. Census was done where all the Secretary Managers from 44 Primary Marketing Co-operative Societies in Nyeri County were the respondents. A self-administered, questionnaire was used to collect data from the target respondents. The study achieved a response rate of $80 \%$. Data analysis was conducted using statistical package for social sciences (SPSS) to generate descriptive and inferential statistics. Frequencies and percentages were generated from the data and presented using frequency distribution tables while linear regression analysis was done to establish relationship of each parameter of the independent variable in the study. The data was tested for linearity using correlation coefficient ( $r$ ) and multicolinearity using Variance Inflation Factor (VIF) respectively. A bivariate linear model was used to assess the influence of members' characteristics on financial performance of Primary Marketing Co-operatives. The study findings revealed that members' characteristics has positive and significant effects on financial performance of Primary Marketing Co-operatives. The study recommends that Primary Marketing Co-operatives should focus on enhancing positive aspects of member characteristics in order to improve their financial performance.

Key words

Members' characteristics, financial performance, primary marketing co-operatives

Received: 12 Dec 2019 (c) The Authors 2019

Revised: 30 Mar 2019 Published by Human Resource Management Academic Research Society (www.hrmars.com)

Accepted: 04 Apr 2019 This article is published under the Creative Commons Attribution (CC BY 4.0) license. Anyone may Published Online: 26 Apr 2019 This article is published under the Creative Commons Attribution (CC BY 4.0) license. Anyone may
reproduce, distribute, translate and create derivative works of this article (for both commercial and non-commercial purposes), subject to full attribution to the original publication and authors. The full terms of this license may be seen at: http://creativecommons.org/licences/by/4.0/legalcode

\section{Introduction}

The modern Cooperative concept started in 1844 in Rochdale village, Manchester, England when Britain was undergoing the industrial distinct identity, history, structure and purpose. According to the International Co-operative Alliance report 2017, there are over 2.6 million co-operatives in the world with over a billion members and directly employing over 250 million people or $12 \%$ of total employed population. Recent statistics show that out of 100 Africans, including children and the elderly, at least seven 
people are members of a co-operative and the total number of co-operatives in most countries has continued to grow (Develtere et al., 2008). Cooperatives take different structural forms in Africa and are broadly organized at two levels: the primary level and the secondary level. At the primary level are cooperative societies with individual persons as members, while co-operative unions are formed at the secondary level with co-operative societies as the members. The history of the Co-operative movement in Kenya dates to the beginning of the $20^{\text {th }}$ Century. The first cooperative society was established by white settlers in 1908 at Lubwa and registered under the Companies Ordinance. Thereafter the Cooperative societies' Ordinance was enacted to govern the registration of co-operative societies in 1931, but was repealed in 1945 to allow Africans to become Cooperative members. Hence the Co-operative movement in Nyeri County started thereafter and especially with registration of coffee Co-operative societies in the 1950 s.

The Co-operative Sector in Kenya has been ranked as number seven worldwide and number one in Africa by ICA in terms of number of enterprises, membership, capital and contribution to national economy (ICA, 2012). Today, Kenya has over 19,200 registered Co-operatives with a total membership of over 14 million members which can be broadly categorized as financial and non-financial Co-operatives (Ministry of Industry, Trade and Co-operatives. 2017). Financial Cooperatives include Savings and Credit Cooperatives (SACCO societies), Union of SACCOs, Housing and Investment Co-operatives. Non-financial co-operative include trading, produce and marketing Co-operatives, (ICA, 2017). The co-operatives continued to be registered and expand in their outreach and impact into farm purchase, savings and credit, housing, handicraft, industrial, transport, workers, consumers, multipurpose, unions and National Co-operative Organizations' (NACO's).As at present there are over 22,000 registered Co-operatives Societies in Kenya. The Co-operative movement in Kenya is an important player in the social economic development of this country. Cooperatives cut across all sectors of the economy and provide an important framework for mobilization of both human and capital resources (Ministry of Co-operative Development and Marketing, 2008).

\subsection{Statement of the Problem}

Primary Marketing Co-operatives are key economic drivers in Kenya with a great potential in eradication of poverty, wealth creation, generation of employment and raising the livelihoods of vulnerable people in the country as noted by Nyoro and Ngugi (2007. Primary Marketing Co-operatives in Kenya are faced with imminent danger of collapsing due to poor financial performance leading to decline in members' patronage. According to Wanyama, (2009) the co-operatives also run short of operating capital to pay wages, purchase of equipment, expansion or meeting other operating costs. Financial underperformance inhibits growth of Primary Marketing Co-operatives by keeping away potential new members and discouraging the already registered members from investing more of their resources. Extensive research has been conducted on co-operative movement in Kenya but specific research work more focused on Members characteristics and financial performance among Primary Marketing Cooperatives remains scanty as noted by Nyoro and Ngugi, (2007); hence an attempt by this study to fill the knowledge gap. Nyeri County is an epitome of vibrant co-operative activities and leads in numbers of both coffee and dairy cooperatives. According to Nadezhda (2009), the financial performance of marketing cooperatives is affected by many factors such as weak management, which causes problems of ineffective resource allocation in their use, low liquidity levels, under developed marketing management, including the absence of certain market niches and non-recognizable brand names. Available information in the county government's co-operative registry, (Nyeri County Annual Reports, 2016) reveals deep rooted problems being faced by some Primary Marketing Cooperatives in Nyeri County threatening their sustainability and survival. Two coffee co-operatives have already been liquidated while three dairy co-operatives have ceased operations. . This study therefore sought to examine the influence of members' characteristics on financial performance of Primary Marketing Co-operatives in Nyeri County. 


\section{Literature review}

\subsection{Theoretical review}

The study was informed and guided by agency theory and stakeholder theory. According to Hoskisson et al. (1999), Agency Theory states that, owing to the division of control and ownership in current corporations, there is frequently a interests deviation between the involved parties: the agent and the principal. Jensen and Meckling (1976) revealed that action of management depart from maximizing returns of the shareholders therefore resulting to the organization problem. In the relationship of principal agent there are two major concerns. The first one is the expense implicated in examining the behavior of the agents and regular actions whereas the second one is the different attitudes held by the agent and principal towards risks (Eisenhard 1989). These problems lead to organization costs which are incurred by the owner or principal in an effort to make sure that managers work in the principal interest (Jensen 1976). Control and ownership separation is vital to guarantee excellent financial performance of corporate which maximizes proceeds to share holder. In relation to the theory, in the presence of information asymmetry the agent (directors as well as the managers) might pursue interests that are divergent from the owners. This was supported by Fama (1983) and Ross (1973).

The stakeholder theory popularized by Freeman, (1994) is underpinned by the assumption that values are necessarily and clearly part of conducting business and put pressure on administration to articulate the manner in which they want to conduct business with what brings core stakeholders together in mind. Beneath this stakeholder theory performance as well as behavior of an organization is believed to be explained and predicted based on its stakeholders, their relative influence on decisions, their values and the situation of an organizational (Brenner and Cochran, 1991), cited in Jones and Wicks, (1999). This theory demands managers to settle the wants of every key stakeholder in the way they run business making it even more attractive to the setup of an organization where stakeholders are differing in objectives as well as wants together with those of a social nature together with the motives of the profit. Donaldson and Preston, (1995) states that even though this theory seeks to explain and describe precise behaviors and characteristics of the corporate, it suffers from not recognizing the fact that stakeholders might be numerous and have interests which are conflicting. In such a condition it's important for all stakeholders' interests in a usual organization to be well reconciled in so as to attain a continued performance of an organization.

\subsection{Empirical literature review}

According to the Scholars; Bhuyan, (2007); Nyoro and Ngugi, (2007); and Chombo,(2009) in their studies on financial performance within the co-operative movement and using various variables namely; competition, members' royalty and active participation; financial, organizational, educational factors, membership and legislative support; members satisfaction and members participation; economic factors, management committee and staff members; respectively were cited as key factors contributing to the financial performance and survival of co-operatives

Osterberg and Nilson, (2009), noted that members of a Primary Co-operative are essentially the principle owners of the entity and in pursuit of their common objective must fulfill their individual responsibilities such as; attending meetings, serving on committees, involvement in recruitment and patronage. The members' participation in Co-operative governance is what distinguishes co-operatives from other organizations of the businesses. Participation is a significant indicator in development of members in understanding and appreciating of the co-operative (USDA, 2005). The literature proposes that participation of members enthused by values of cooperative is vital for co-operative sustainability. Several researchers have disputed that sustainability of co-operatives depends on identity sense of members, cohesion as well as commitment (Birchall et al., 2004). According to Akinwunmi (2006), leadership is a critical element affecting financial performance of Co-operatives. He asserts that if leaders are transparent, truly serving and dedicated, if there is determined leadership, the Co-operative Society will be successful adding that true leaders do not cut corners, do not increase contracts in order to receive kickbacks, will not have favorites amongst members as well as will not misuse the available resources.

The concerns on the leaders' caliber who manage SACCOs were raised and it was noted that because these are voluntary organizations, members could appoint anyone they prefer, who might not essentially 
have the skills to manage a SACCO (Mudibo, 2005). This in most cases results to election of people whose integrity is questionable but who are able to influence electors through bribes. The researcher proposed that prior to the election of a member, they must have a certain shares number in order that they have something to lose if they mishandle the SACCO. Increased member patronage as noted by Jensen et al (1976) provides an important source of Co-operative capital adding that the more members use and benefit from the Co-operative services, the more surplus funds the Co-operative will generate. It is therefore important to try and increase member patronage through training of members and also offering better services.

\subsection{Conceptual Framework}

Bell (2010), described a conceptual framework as a diagrammatical representation showing the association between independent and dependent variables. The figure below is a diagrammatical representation of the conceptual framework showing financial performance of Primary Marketing Cooperatives being dependent on members' characteristics.

\begin{tabular}{|c|c|}
\hline Independent Variable & Dependent Variable \\
\hline $\begin{array}{l}\text { Members' characteristics } \\
\text { - Age in years. } \\
\text { - Income Levels. } \\
\text { - Patronage levels in years. }\end{array}$ & $\begin{array}{l}\text { Financial Performance } \\
\text { - } \quad \text { Net Profit after Tax. } \\
\text { - } \text { Return on Investment. } \\
\text { - } \text { Gross Profit Margin. } \\
\text { - } \quad \text { Profitability Index }\end{array}$ \\
\hline
\end{tabular}

Figure 1. Conceptual framework

\section{Methodology of research}

A descriptive design of study was believed to be the most excellent design to the study's objectives. According to Mugenda and Mugenda (2003), a descriptive study is mainly concerned with finding out the where, how and what of an occurrence. The study's target population was the 44 Primary Marketing Cooperatives in Nyeri County. The Secretary Managers of the 44 Primary Marketing Co-operative Societies or their assistants in their absence formed the group of respondents from whom opinion was sought through filling of questionnaires. Kothari (2004) defines population as the whole group of items or people under contemplation in any field of investigation and have a universal quality. Due to the small number of Primary Marketing Co-operatives in Nyeri County, the researcher used census instead of sample size. In this research the questionnaires were utilized to get the relevant data aimed at answering the research questions.

To test the questionnaires' reliability as well as validity, a pilot study was conducted. Pilot testing was done to find out the appropriateness and accuracy of the design of research and research instrument (Bryman, 2007; Zikmund et al., 2010). The study used Cronbach's alpha coefficient to establish the reliability of internal consistency where alpha value of greater than 0.7 was deemed reliable. Pilot test of this study gave the alpha values of 0.763 which was greater than 0.70 . This implies that the instrument of data collection was consequently acceptable and reliable for the study's purposes.

The gathered data, with the aid of questionnaire was systematically organized specifically to facilitate analysis. Descriptive statistics was utilized to analyze the collected data by use of the Statistical Package for Social Science (SPSS) version 20.0 by first coding the responses. In addition, linear regression was utilized to analyze the effect of members' characteristics on financial performance of primary marketing co-operatives in Nyeri County. The model of linear regression is:

$\mathrm{Y}=\beta \mathrm{O}+\beta_{1} \mathrm{X}_{1}+\beta_{2} \mathrm{X}_{2}+e$

Where:

$\mathrm{Y}=$ Financial performance of Primary Marketing Co-operatives

$\beta o=$ Autonomous factor 
$\beta_{1}=$ beta coefficient of members' characteristic

$\mathrm{X}_{1}=$ Members' characteristic

$e=$ The error term.

\subsection{Research findings}

The researcher administered 44 questionnaires of which 35 responses were filled and returned giving a response rate of $80 \%$ of the target population. This response rate is within recommendation of Mugenda and Mugenda (2003) who stipulated that a response rate of $70 \%$ and above is excellent.

Response by Nature of Business Undertaken

The researcher sought to establish the nature of business undertaken by respective Primary Marketing Co-operative Society. The results of findings are analyzed in Table 1.

Table 1. Results for Nature of business

\begin{tabular}{lccc}
\hline \multicolumn{2}{c}{ Nature of business } & Frequency (n) & Percent (\%) \\
\hline Dairy marketing & 17 & 49 \\
Coffee marketing & 18 & 51 \\
& Total & $\mathbf{3 5}$ & $\mathbf{1 0 0 . 0}$ \\
\hline
\end{tabular}

From Table 1 , the results indicate that $49 \%$ and $51 \%$ of the respondents were derived from Dairy Marketing and Coffee marketing respectively. The study revealed that both cooperatives were adequately represented in this study.

Age of Respondents

The researcher sought to establish the age category of the respondents.

Table 2. Results for Age of Respondents

\begin{tabular}{lccc}
\hline \multicolumn{1}{c}{ Range (years) } & Frequency $(\mathbf{n})$ & Percent \\
\hline 01 to 30 years & & 2 & 6 \\
31 to 50 years & 31 & 88 \\
51 years and over & 2 & 6 \\
& & $\mathbf{3 5}$ & $\mathbf{1 0 0 . 0}$ \\
\hline
\end{tabular}

Majority of the respondents (88\%) were in the age bracket of 30 to 50 years. This is a clear indication that they are in their productive stage in life and if properly managed which leads to increased performance for the entire organization.

Gender of the Respondents

The researcher sought to establish gender distribution of the respondents.

Table 3. Results for Gender of the Respondents

\begin{tabular}{lccc}
\hline \multicolumn{2}{c}{ Gender of the Respondents } & Frequency $(\mathbf{n})$ & Percent (\%) \\
\hline Female & 13 & 37 \\
Male & & 22 & 63 \\
& Total & $\mathbf{3 5}$ & $\mathbf{1 0 0 . 0}$ \\
\hline
\end{tabular}

A third of the respondents were female while two third were male. The indication was that Primary Marketing Co-operative Societies have adhered to a third gender rule as promulgated by the Kenya Constitution.

\section{Education Qualification of Respondent}

The study sought to establish the level of education of the respondents. Table 4.5 presents the academic profile of the respondents. 
Table 4. Results for Educational Qualification

\begin{tabular}{|c|c|c|}
\hline Educational Qualification & Frequency (n) & Percent (\%) \\
\hline Certificate & 9 & 26 \\
\hline Diploma & 25 & 71 \\
\hline Degree & 1 & 3 \\
\hline Total & 35 & 100.0 \\
\hline
\end{tabular}

The findings indicates that majority of the staff working with Primary Marketing Co-operatives were Certificate or Diploma holders which accounted for $26 \%$ and $71 \%$ respectively. This is a clear indication that Primary Marketing Co-operative Societies are properly equipped with appropriate personnel at the managerial level and were therefore able to articulate issues prompted by this questionnaire.

Respondents' Position within the Co-operative Society

The researcher sought to establish the position held by the respective respondents. The Table 5 below gives the positions held by respondents.

Table 5. Results for Respondents' Position in the Co-operative Society

\begin{tabular}{lccl}
\hline \multicolumn{2}{c}{ Position in the Society } & Frequency (n) & Percent (\%) \\
\hline Manager & & 20 & 57 \\
Assistant manager & 15 & 43 \\
& Total & 35 & 100.0 \\
\hline
\end{tabular}

The respondents of this questionnaire were in managerial positions which indicate that they had the requisite authority to fill the questionnaire.

\section{Work Experience of the Respondents}

The researcher sought to know the number of years worked by respective respondents and ascertain to what extent their responses could be relied upon in making conclusions for the study. The results were analyzed in the table below:

Table 6. Results for Work Experience

\begin{tabular}{lccc}
\hline & Range (Years) & Frequency (n) & Percent (\%) \\
\hline $0-5$ years & & 3 & 9 \\
$6-10$ years & & 12 & 34 \\
Over 10 years & & 20 & 57 \\
& Total & 35 & $\mathbf{1 0 0 . 0}$ \\
\hline
\end{tabular}

Most respondents were equipped with the appropriate experience with $57 \%$ frequency having worked in the organization for over 10 years. This indicates that experienced personnel are in place that is able to fully understand and respond to the questionnaire accordingly.

\section{Descriptive Analysis for Study Variables}

The researcher carried out descriptive analysis for the dependent and the independent variables of the study. The results were discussed below.

\section{Descriptive Analysis for Financial Performance}

Performance is referred to the ability to operate efficiently, profitability, survive grow and react to the environmental opportunities and threats. Dixon et al. (1990) said that appropriate performance measures are those which enable organizations to direct their actions towards achieving their strategic objectives. They noted that performances measures includes; ROI, profitability and goal attainment. This study sought to establish the performance of Primary Marketing Co-operatives. 
Table 7. Financial Indicators of the Primary Marketing Co-operatives.

\begin{tabular}{lcccc}
\hline & N & Mean & Std. Error & Std. Deviation \\
\hline NEPAT (Kshs) & 35 & 63325.6457 & 4221.7764 & 24976.3658 \\
ROI (\%) & 35 & 11.7886 & .7590 & 4.4902 \\
Gross profit margin (\%) & 35 & 13.8114 & .3912 & 2.3146 \\
Profitability index (Ratio) & 35 & 1.0933 & .0119 & .0702 \\
Valid N & 35 & & & \\
\hline
\end{tabular}

The finding of the study revealed that average net profit after tax for the cooperative societies was $63,325.65$ with a std dev $=24976.37$. The average return on investment was 11.79 with a std dev $=4.49$, mean gross profit margin was 13.81 with a std dev $=2.32$ while average profitability index was 1.09 with a std dev $=0.07$. The finding indicate that the mean return on investment is 11.79 and the Primary Marketing Co-operatives are viable since profitability index is greater that one.

\section{Descriptive Analysis for Members Characteristics}

Objective one of the study sought to examine influence of members' characteristics on financial performance of Primary Marketing Co-operatives in Nyeri County. Descriptive statistics were done to determine the effect of various factors of members' characteristics. Table 8 to 11 shows the effect of each factor of members' characteristics on financial performance of Primary Marketing Co-operatives.

\section{Average Age of Cooperative Society Members}

The researcher sought to establish the average age of members in Primary Marketing Co-operative Societies.

Table 8. Results for Age of Cooperative Members

\begin{tabular}{lccc}
\hline & Range (years) & Frequency $(\mathbf{n})$ & Percent (\%) \\
\hline 20 years and below & 1 & 3 \\
$21-30$ years & 3 & 9 \\
$31-40$ years & 20 & 57 \\
$41-50$ years & & 9 & 26 \\
Above 50 years & Total & 2 & 5 \\
& & 35 & 100.0 \\
\hline
\end{tabular}

The finding of the study revealed that majority of the members' are aged between 31 to 50 years which accounted for $83 \%$. The finding indicate that most of the members are within their productive age where they are expected to generate more revenue as a result of various responsibilities pertaining to providing for the families with basic needs and education.

\section{Member's Average Monthly Income}

The researcher sought to establish the average monthly incomes of members in Primary Marketing Co-operative Societies.

Table 9. Results for Member's Average Monthly Income

\begin{tabular}{ccc}
\hline Range (Kshs) & Frequency $(\mathbf{n})$ & Percent $(\%)$ \\
\hline 5000 and below & 7 & 20 \\
$5,001-10,000$ & 24 & 68 \\
$10,001-20,000$ & 3 & 9 \\
$20,001-30,000$ & 1 & 3 \\
Total & 35 & 100.0 \\
\hline
\end{tabular}

As shown in Table 9, majority of the members' earn a monthly income of below 10,000 . The monthly income of members is of low factor that might lead to members' reluctance in coffee production which 
causes low financial performance. Similarly, income from milk production was also noted to be low. Most of the members had a low production in kilogram and this affects the profitability of the societies.

\section{Members Patronage}

The researcher sought to establish the percentage of members who fully patronize the Primary Marketing Co-operative Societies.

Table 10. Results for Member's Patronage

\begin{tabular}{ccc}
\hline Range (\%) & Frequency (n) & Percent (\%) \\
\hline $21-30 \%$ & 7 & 20 \\
$31-40 \%$ & 10 & 29 \\
$41-50 \%$ & 18 & 51 \\
Total & 35 & 100.0 \\
\hline
\end{tabular}

The study revealed that the level of members' patronage to the co-operatives activities is between 41-50\%. This indicates that member patronage levels are low due to competition with middlemen which in effect reduces production and overall financial performance of the Primary Marketing Co-operative Societies.

Table 11. Descriptive Statistics for Members Characteristics

\begin{tabular}{lcccc}
\hline & $\mathbf{N}$ & Mean & Std. Error & Std. Deviation \\
\hline $\begin{array}{l}\text { Income level of members affects performance of primary } \\
\text { marketing co-operatives }\end{array}$ & 35 & 4.31 & .187 & 1.105 \\
$\begin{array}{l}\text { Age of the member is a factor that affect performance of } \\
\text { cooperative }\end{array}$ & 35 & 3.74 & .185 & 1.094 \\
$\begin{array}{l}\text { level of member patronage in the co-operative activities } \\
\text { affect performance }\end{array}$ & 35 & 3.11 & .168 & .993 \\
Valid N (list wise) & 35 & & & \\
\hline
\end{tabular}

As shown in Table 11, Income level of members was ranked as the most important factor that influence performance of Primary Marketing Co-operatives (mean $=4.31)$ with a $(s t d v=1.105)$. Age of the member was ranked as the second factor that affect performance of cooperative (mean $=3.74$ ) with a (stdv $=1.094$ ). The level of members patronage in the co-operatives activities had a mean of 3.11 (stdv $=0.993$ ). Therefore the study revealed that members age and level of income has a major role to play on performance of Primary Marketing Co-operatives.

\section{Test of Regression Assumption}

Prior to running a regression model multicollinearity test and linearity test were performed to avoid spurious regression results from being obtained.

\section{Linearity Test}

To establish the nature and magnitude of the relationships between the variables and to test the hypothesized relationships, the researcher used Pearson's Product Moment Coefficient Correlation ( $r$ ) to establish any linear associations among the variables in the study, as well as their nature and strength. This measure, usually symbolized by the letter $(r)$, varies from ranging from -1 to +1 , with 0 indicating no linear association. In order to conduct correlation analysis the set of items that measured each variable were aggregated by computing the average. The findings of the analysis are as indicated in Table 9.

Table 12. Correlation Analysis

\begin{tabular}{llcc}
\hline & Correlation analysis & Performance & Member \\
\hline \multirow{2}{*}{ Member Characteristics } & Pearson Correlation & $.341^{*}$ & 1 \\
& Sig. (2-tailed) & .045 & \\
\hline
\end{tabular}


From the correlation matrix, member characteristics was positively and significantly related to financial performance of primary cooperatives $r=0.341$, $p$ value $0.045<0.05$ at 0.05 significance level. This indicates a linear relationship between member characteristics and financial performance.

\section{Test of Multicollinearity}

Multicollinearity occurs when more than two predictor variables are inter-correlated, Kothari (2004). This is an undesirable situation where the correlations among the independent variables are strong as it increases the standard errors of the coefficients. To test for multicollinearity, Variance Inflation Variable (VIF) or tolerance, a diagnostic method was used to detect how severe the problem of multicollinearity is in a multiple regression model. VIF statistic of a predictor in a model indicates how much larger the error variance for the unique effect of a predictor (Baguley, 2012). Using the VIF method, a tolerance of less than 0.20 and a VIF of more than 5 indicates a presence of multicollinearity. If two or more variables have a Variance Inflation Factor (VIF) of 5 or greater than 5, one of these variables must be removed from the regression analysis as this indicates presence of multicollinearity (Runkle et al., 2013). From Table 10 there is no VIF with a value of 5 or greater than 5 and therefore no presence of multicollinearity.

Table 13. Multicollinearity Test Results

\begin{tabular}{lcc}
\hline \multicolumn{1}{c}{ Model Independent variables } & \multicolumn{2}{c}{ Collinearity Statistics } \\
\hline (Constant) & Tolerance & VIF \\
Member characteristics & & \\
\end{tabular}

\section{Regression analysis}

A bivariate linear regression analysis was done by regressing the weighted scores of the members' characteristics on financial performance. The results are presented in Tables 11 to 13.

\section{Influence of Members' Characteristics on Financial Performance}

A bivariate linear regression analysis was done by regressing the weighted scores of the members' characteristics on financial performance. The results are presented in Tables 14 to 16.

Table 14. Model Summary for Members Characteristics

\begin{tabular}{ccccc}
\hline Model & $\mathbf{R}$ & $\mathbf{R}$ Square & Adjusted R Square & Std. Error of the Estimate \\
\hline 1 & $.341^{\text {a }}$ & .116 & .089 & 1.18662 \\
\hline
\end{tabular}

a. Predictors: (Constant), Member

From the regression results in Table 14, the $R$ value was 0.341 indicating that there is a relationship between members' characteristics on performance of Primary Marketing Co-operatives. The R squared $\left(R^{2}\right)$ value of 0.116 shows that 11.6 percent of the performance of Primary Marketing Co-operatives is explained by members' characteristics all other factors held constant. The remaining 88.4 percent is explained by other factors.

Table 15. ANOVA for Members Characteristics

\begin{tabular}{ccccccc}
\hline & Model & Sum of Squares & df & Mean Square & F & Sig. \\
\hline \multirow{2}{*}{1} & Regression & 6.105 & 1 & 6.105 & 4.336 & $.045^{\mathrm{b}}$ \\
& Residual & 46.467 & 33 & 1.408 & & \\
& Total & 52.571 & 34 & & & \\
\hline
\end{tabular}

a. Dependent Variable: Performance

b. Predictors: (Constant), Member

The model was significant with the $F$ ratio $=4.336$ at $p$ value $0.045<0.05$. This is an indication that members' characteristics when considered singly have a statistically significant effect on financial performance of Primary Marketing Co-operatives. 
Table 16. Regression Coefficients for Members Characteristics

\begin{tabular}{ccccccc}
\hline \multirow{2}{*}{ Model } & \multicolumn{2}{c}{ Unstandardized Coefficients } \\
B & $\begin{array}{c}\text { Std. Error } \\
\text { B }\end{array}$ & $\begin{array}{c}\text { Standardized Coefficients } \\
\text { Beta }\end{array}$ & t & Sig. \\
\hline \multirow{2}{*}{ (Constant) } & 2.232 & .674 & & 3.311 & .002 \\
& Member & .378 & .182 & .341 & 2.082 & .045 \\
\hline
\end{tabular}

a. Dependent Variable: Performance

Members' characteristics had positive and significant effect on performance of Primary Marketing Co-operatives with $\beta=0.378$ at $p$ value 0.045 which is less than 0.05 . From Table 4.26 , the bivariate linear regression model fitted using unstandardized coefficients is; $Y=2.232+0.378 \mathrm{X}_{1}+\mathrm{e}$. In this model 2.232 is an exogenous variable in the regression model and $X_{1}$ is members' characteristics index. This means that members' characteristics are positively and significantly influencing performance of Primary Marketing Cooperatives. It also means that an increase of one unit of $X_{1}$ increases $Y$ by 0.378 . The indication was that members' characteristics can be adopted when evaluating performance of Primary Marketing Cooperatives.

The finding of the study revealed that members characteristic had positive and significant effect on performance of Primary Marketing Co-operatives when considered singly and when combined with other variables supports earlier findings by Osterberg and Nilson (2009), who noted that members of a Primary Co-operative are essentially the principle owners of the entity and in pursuit of their common objective must fulfill their individual responsibilities such as; attending meetings, serving on committees, involvement in recruitment and patronage. The literature suggests that a membership participation inspired by co-operative values is crucial for co-operative sustainability.

According to USDA (2005), participation is an important indicator in developing members in understanding and appreciating of the cooperative. A number of writers have argued that co-operatives' sustainability depends on members' sense of identity, commitment and cohesion (Birchall et al. 2004). However membership loyalty and commitment depend on co-operatives' ability to meet members' needs and demands.

\section{Conclusions}

The objective of the study was to examine influence of members' characteristics on financial performance of Primary Marketing Co-operatives in Nyeri County. The study accentuates that at $5 \%$ level of significance the regression results indicated a positive and statistical significant relationship between members' characteristics and financial performance of Primary Marketing Co-operatives. Descriptive analysis revealed that income level of members and the age of the members were major factor that affects performance of Primary Marketing Co-operatives. The indication was that as income increases the percentage of reserve to the Co-operative will increase hence boosting the financial position. In addition, the age of the member determine whether they are in early thirties when they are expected to generate more revenue as a result of various responsibilities hence increasing production. The level of member patronage in the Co-operatives activities was found to have minimal effect on performance.

\section{Recommendations}

The study made the following recommendations for the improvement of members' characteristics and financial performance of Primary Marketing Co-operatives in Nyeri County. The societies should look for the ways of improving the number of products dealt with through diversification in order to improve their financial performance when members make use of such products. The managers should also find ways of improving the membership of these societies to increase the number of members through membership drives and outreach activities. Future researchers should focus on other characteristics such as staff, commodity and market characteristics in order to establish their relationship with financial performance of Primary Marketing Co-operative 


\section{References}

1. Akinwumi, J. (2006). Road Map to re-engineering Co-operatives in Nigeria; A paper presented at the south west co-operative leaders conference, organized by co-operative federation of Nigeria South west zone at Obisesan Hall, Ibadan, September 7th.2006.

2. Almazari A. A. (2011). Financial Performance Evaluation of Some Selected Jordanian Commercial Banks.International Research Journal of Finance and Economics. ISSN 1450-2887 Issue 68 (2011).

3. Bell, J. (2010). Doing Your Research Project: A Guide for First-Time Researchers in Education, Health and Social Science (2nd Ed.). Buckingham, England: McGraw-Hill International. [2] Breaugh, J. A. (2008). Employee recruitment.

4. Birchall, J. (2004), Co-operatives and the Millennium Development Goals, ILO.

5. Birchall, J. and Richard, A. S. (2004). What motivates members to participate in co-operative and mutual businesses? A theoretical model and some findings. Annals of Public \& Cooperative Economics 75(3):465-495.

6. Brenner, S. \& Cochran, P. L. (1991).The stakeholder model of the firm: Implications for business and society theory and research. Proceedings of the International Association for Business and Society, 449467.

7. Bryman, A. and Bell, E. (2003).Business Research Methods. Oxford, Oxford University Press.

8. Burns, N. and Grove, S. (2002). The practice of nursing research: conduct, critique and utilization (4th ed). W.B.Saunders: Philadelphia, Pennsylvania, USA.

9. Cropp, B. and Graf, T. (2001).The History and Role of Dairy Cooperatives. lowa State University Press, lowa,

10. Davis, J. H., Schoorman, F. D., \& Donaldson, R. (1997).Toward a stewardship theory of management. Academy of Management Review, 22(1), 20-47.

11. Donaldson, L. and Davis, J.H. (1994). Boards and company performance Research challenges the conventional wisdom, Corporate Governance: An International Review, 2, 151-160.

12. Donaldson, L., \& Davis, J. H. (1991). Stewardship theory or agency theory: CEO governance and shareholder returns. Australian Journal of Management, 16(1): 49-64.

13. Donaldson, L., \& Davis, J. H. (1991).Stewardship Theory or Agency Theory: CEO governance and shareholder returns. Australian Journal of Management, 16: 49-65.

14. Donaldson, T and Preston, L (1995) 'The Stakeholder Theory of the Corporation: Concepts, Evidence, and Implications' The Academy of Management Review, Vol. 20, No. 1, Pp. 65-91.

15. Donaldson, T., \& Preston, L. E. (1995).The stakeholder theory of the corporation: Concepts, evidence, and implications. Academy of Management Review, 20:65-91.

16. Eisenhardt, M., K. (1989). Agency Theory: An assessment and review. Academy of Management Review, 14(1): 57-74.

17. Fama, E.F., Jensen, M. C. (1983). Agency Problems and Residual Claims. Journal of Law \& Economics, 26: 327-350.

18. Frankfort-Nachmias, C. \& Nachmias, D. (2008).Research methods in social sciences (7th ed.). New York: Worth Publishers.

19. Freeman, R.E (1994) 'The Politics of Stakeholder theory: Some future directions' Business Ethics Quarterly, Vol. 4(4), 409 - 421

20. Gay, L. R., Mills, G. E., \&Airasian, P. W. (2009).Educational research: Competencies for analysis and applications (9th edition). Upper Saddle River, New Jersey: Prentice Hall.

21. Hoskisson, R.E., Hitt, M.A., Wan, W.P., and Yiu, D. (1999). Theory and research in strategic management.Journal of Management 25 (3): 417-456

22. Hoskisson, R.E., Hitt, M.A., Wan, W.P., \& Yiu, D. (1999).Journal of Management, 25: 417- 456.

23. International Cooperative Alliance.(2006). ICA Group 300 Report. Retrieved March10, 2011, from http://www.ica.coop/publications/ar/2006annualreport.pdf.

24. International Monetary Fund (2007) Kenya: Poverty Reduction Strategy Annual Progress Report.2004/2005, IMF Country Report No. 07/159, International Monetary Fund. Washington, D.C.

25. Jensen, M. C., \& Meckling, W. H. (1976). Theory of the firm: Managerial behavior, agency costs and ownership structure. Journal of Financial Economics, 3: 305-360. 
26. Jones, T. M., \& Wicks, A. C. (1999). Convergent stakeholder theory. Academy of Management Review, 24:206-21.

27. Kombo, D.K. and Tromp, D.L.A. (2009). Proposal and Thesis Writing: An Introduction. Paulines Publications Africa, Don Bosco Printing Press, Nairobi Kenya.

28. Kothari, C.R. (2004). Research methodology: Methods and techniques. (2nd ed.). New Delhi: New Age international ltd.

29. Makhija, M. (2003). Comparing the resource-based and market-based views of the firm: Empirical evidence from Czech Privatization. Strategic Management Journal, 24, 433-451.

30. Ministry of Co-operative Development and Marketing, (2008) Co-operative Development Policy, Nairobi, Ministry of Co-operative Development and Marketing.

31. Mudibo, E.K. (2005), "Highlights of the SACCO movement and current trends in the Kenya Union of Savings and Credit Co-operatives (KUSCCO)', KUSCCO, Nairobi.

32. Mugenda, O. \& Mugenda, A.G. (2003). Research Methods: Qualitative and Quantitative Approaches. Nairobi. Acts Press.

33. Mugenda, O. M. and Mugenda, A. G. (2008). Research methods: quantitative and qualitative approaches. Nairobi. Acts press

34. Nyoro J.K. and Ngugi,I.K. (2007). A qualitative analysis of success and failure factors of agricultural co-operatives in central Kenya. Available on:http://www. Tegemeo. Org/viewdocument.asp? $I D=145$

35. Osterberg, P., \& Nilsson, J. (2009). Members' perception of their participation in the governance of cooperatives: The key to trust and commitment in agricultural cooperatives. Agribusiness, 25, 181-197

36. Pandey, I.M. (1999). Financial Management, Eighth Edition. Vikas Publishing House PVT Ltd, New Delhi, India.

37. Republic of Kenya (1997a) Sessional Paper No. 6 of 1997 on Cooperatives in a Liberalized Economic Environment, Nairobi, Government Printer.

38. Republic of Kenya (1997b), Co-operative Societies Act, 1997, Government Printer, Nairobi.

39. Ross, Stephen A. (1973). The economic theory of agency: The principal's problem. American Economic Review 62(2): 134-139.

40. Royston P. (1991), Estimating departure from normality. Stat Med. 10(8):1283-93.

41. The International Cooperative Alliance (ICA 2017)

42. Torraco, R. J. (1997). Theory-building research methods. In R. A. Swanson \& E. F. Holton III (Eds.), Human resource development handbook: Linking research and practice (pp. 114-137). San Francisco: Berrett-Koehler.

43. Trochim, W.M.K. (2006). Research methods knowledge base. Retrieved on January 25, 2010 from http://www.socialresearchmethods.net

44. USDA - Rural Business Cooperative Service. (2005). Marketing Cooperative by Type, Memberships and Sales. http://www.rurdev.usda.gov/rbs/coops/data.htm (Accessed February 4, 2013).

45. Verma, S.K. (2004) "Cooperative Centenary in India", New Sector Magazine, Issue No 61, April/ May 2004.

46. Zikmund, G.W., Babin, B.J., Carr, C.J. and Griffin, M. (2010). Business Research Methods $8^{\text {th }}$ ed. South-Western, Cengage Learning. 